\title{
Vitamin D receptor gene polymorphisms as a risk factor for obesity in Saudi men
}

Ayman Saeed Al-hazmi ${ }^{1}$, Mazin Mohammed Al-Mehmadi ${ }^{1}$, Sarah Mohammad Al-Bogami ${ }^{2}$, Ashjan Ali Shami ${ }^{1}$, Ahmad El Askary ${ }^{1,3}$, Anas Mohammad Alomery ${ }^{1}$, Saad Saeed Al-Shehri ${ }^{1}$, Haytham Dahlawi ${ }^{1}$, Khadija

Abdulrazag ${ }^{4}$, Tarek Mohamed Ali ${ }^{1,5}$, Abdalaziz Al-Bogami ${ }^{4}$, Emad Sheshah ${ }^{4}$, Abdalaziz Al-Mutairi ${ }^{4}$, Salh AlSuhimi ${ }^{4}$, Faris Alharb ${ }^{2}$

${ }^{1}$ Faculty of Applied Medical Sciences, Taif University, Taif city, Saudi Arabia

${ }^{2}$ Faculty of Sciences, Taif University, Taif city, Saudi Arabia

${ }^{3}$ Department of Medical Biochemistry, Faculty of Medicine (New Damietta), Al-Azhar University, Egypt

${ }^{4}$ Laboratory Specialist, King Faisal Hospital, Taif city, Saudi Arabia

${ }^{5}$ Physiology Department, Faculty of Medicine, Beni-Suef University, Egypt

\section{Type of article: Original}

\begin{abstract}
Background: The prevalence of obesity and vitamin D deficiency in Saudi Arabia has increased recently. Decreased physical activity might play a role in obesity. Previous studies showed an association between low vitamin D level and its receptor polymorphism with obesity development.

Objective: To determine association of low vitamin D level and its receptor polymorphism with obesity in Saudi men.

Methods: This case control study was carried out from March 2016 through March 2017. Three hundred Saudi male students (from applied medical sciences in Taif University, Taif, Saudi Arabia) were classified according to BMI into lean, overweight and obese groups. For each individual, blood glucose, cholesterol, HDL-C, LDL-C, insulin and 25-(OH) vitamin D were measured. In addition, Apal, BsmI and TaqI genotypes were performed for each individual from March 2016 through March 2017, through computer-based search of the following databases: PubMed, Web of Science (Thomson Reuters ${ }^{\mathrm{TM}}$ ). The references of the original literature and the related articles were also searched, for potential complementary studies. Data were analyzed by SPSS version 16, using Spearman's rho and ANOVA tests.

Results: There was significant negative association between $25-(\mathrm{OH})$ vitamin D level and obesity $(\mathrm{p}<0.01)$. Genotyping study showed that both bb of BsmI and tt of TaqI genotypes were higher in the obese group compared with lean group $(\mathrm{p}<0.05)$. Moreover, bb genotype has higher BMI and HOMA-IR than both BB and $\mathrm{Bb}$; and tt genotype also has higher BMI and HOMA-IR than TT and Tt genotypes $(\mathrm{p}<0.05)$.

Conclusion: Low vitamin D level and VDR BsmI and Taq1 genotypes may be a risk factor of obesity.

Keywords: Vitamin D receptor, Obesity, Genetic polymorphism
\end{abstract}

\section{Introduction}

Obesity is a complex chronic metabolic disease defined as a body mass index (BMI) of $\geq 30 \mathrm{Kg} / \mathrm{m}^{2}$ (1). It is characterized by accumulation of excessive body fat resulting from metabolic imbalance between energy intake and expenditure (2). Obesity has become a global health problem that is associated with the development of type 2 diabetes mellitus, hypertension and cardiovascular diseases (3). It affects over 500 million people worldwide, and in Saudi Arabia its prevalence has elevated to affect $34 \%$ of adults (4). Besides environmental factors, genetic differences play an important role in the development of obesity (5). Vitamin D is a fat-soluble vitamin, obtained either from exposure to sunlight or through dietary intake (2). The ultraviolet light converts 7-hydrocholesterol

\section{Corresponding author:}

Associate Professor Dr. Ayman Saeed Al-hazmi, Faculty of Applied Medical Sciences, Taif University, Taif city, Saudi Arabia. Tel.: 00966555512052, Email: omarianas1@hotmail.com

Received: June 05, 2017, Accepted: August 30, 2017, Published: October 2017

iThenticate screening: August 31, 2017, English editing: September 21, 2017, Quality control: October 05, 2017

This article has been reviewed / commented by three experts

(C) 2017 The Authors. This is an open access article under the terms of the Creative Commons Attribution-NonCommercialNoDerivs License, which permits use and distribution in any medium, provided the original work is properly cited, the use is non-commercial and no modifications or adaptations are made. 
present in the skin into inactive vitamin D precursors. This precursor converts into active form through two hydroxylation reactions occurring in the liver and kidney. It is responsible for bone health, immunity, and regulates growth and differentiation of various cell types (6). The deficiency of vitamin D is highly distributed worldwide. In Saudi Arabia, which is a sunny area, previous studies showed that the vitamin D deficiency and insufficiency reached up to $90 \%$ of all study samples (7). Several studies suggest that serum level of $25(\mathrm{OH})$-vitamin D is associated with obesity and its complications (8). Previous studies found that low vitamin D level, increases obesity risk in women because the women in Saudi Arabia are not exposed to sunshine (9). Active vitamin-D form, exerts its effect through interaction with vitamin-D receptors (VDR). These receptors are highly expressed in preadipocytes from obese subjects (10). Recent study found that the active form of vitamin D induces both VDR expression and adipogenesis (11). Moreover, a study done on transgenic mice that over-express human VDR in adipocytes, showed marked decreases in energy expenditure and development of obesity (12). Thus, this study was aimed to determine the association between the variables "low vitamin D level and its receptor polymorphisms Apal, BsmI and TaqI" and the development of obesity in Saudi subjects.

\section{Material and Methods}

\subsection{Setting and subjects}

The present research was a case control study. Three hundred Saudi male students were classified according to BMI into lean, overweight and obese groups. For each individual, blood glucose, cholesterol, HDL-C, LDL-C, insulin and 25-(OH) vitamin D were measured. In addition, Apal, BsmI and TaqI genotypes were performed for each individual from March 2016 through March 2017 through computer-based searches of the following databases: PubMed, Web of Science (Thomson Reuters ${ }^{\mathrm{TM}}$ ). The references of the original literature and the related articles were also searched for potential complementary studies. We confirmed that no subject included in this study suffered from any chronic diseases such as diabetes mellitus or hypertension and no medications or vitamin supplementation were taken. After an overnight fast, blood samples were obtained in ethylene diamine tetra acetic acid (EDTA) in plain tubes, then separated immediately.

\subsection{Ethics of research}

Approval for the study was obtained from the Scientific Research Ethics Committee of Taif University with the reference number 142350 .

\subsection{Data collection}

\subsubsection{Biochemical markers:}

The plasma was used for biochemical markers include glucose, triglyceride, total cholesterol, HDL-C, LDL-C, insulin and 25-(OH) vitamin D. Triglyceride, cholesterol, HDL-C and LDL-C were measured in a dimension autoanalyzer (Dade Behring Inc). Insulin and 25-(OH) vitamin D were measured by using ELISA technique (13). Homeostasis model assessment for insulin resistance (HOMA-IR) was calculated as (fasting insulin (uIU/mL) $\mathrm{x}$ fasting glucose $(\mathrm{mmol} / \mathrm{L}) / 22.5$.

2.3.2. Genotyping:

Blood samples collected in EDTA tubes where the DNA was extracted from peripheral blood leukocytes using the Thermo SCIENTIFIC DNA isolation kit (Thermo SCIENTIFIC) (14). Genomic DNA was amplified and analyzed for VDR genotype by polymerase chain reaction (PCR) and restriction fragment length polymorphisms (RFLP) for both Taq1 and Apal genotypes using forward and reverse primers showed in Table 1. The PCR mix contained $5 \mu \mathrm{L}$ of each primer (10 pmol), $5 \mu \mathrm{L}$ buffer, $1.5 \mu \mathrm{L} \mathrm{MgCl} 2(50 \mathrm{mM}), 5 \mu \mathrm{L}$ template DNA (50-100 ng), $5 \mu \mathrm{L}$ dNTPs $(2$ $\mathrm{mmol} / \mathrm{L}$ ), Taq polymerase (MBI) $2 \mu \mathrm{L}, \mathrm{H} 2 \mathrm{O} 26.5 \mu \mathrm{L}$. The DNA template was denatured at $95^{\circ} \mathrm{C}$ for 2 minutes. A total of 40 cycles of PCR were performed, consisting of denaturation step for 45 seconds at $94{ }^{\circ} \mathrm{C}$, an annealing step for 45 seconds at optimum temperature $\left(67^{\circ} \mathrm{C}\right.$ for ApaI/TaqI and $60^{\circ} \mathrm{C}$ for BsmI), and an extension reaction for 1 minute at $72{ }^{\circ} \mathrm{C}$. A final extension step at $72{ }^{\circ} \mathrm{C}$ for 2 minutes was added after the last PCR cycle. After amplification, the PCR products were digested by incubation with restriction enzymes. For ApaI polymorphism, the amplicon incubated with ApaI enzyme in $37 \mathrm{C}$ for 5 minutes to get its three genotypes on $1.5 \%$ agarose gel designated AA, Aa and aa. Incubation of amplicon with TaqI at $65^{\circ} \mathrm{C}$ for 4 hours produced TT, Tt and tt on $2.5 \%$ agarose gel. BsmI genotypes were produced after incubation of amplicon with BsmI enzyme at $65{ }^{\circ} \mathrm{C}$ for 15 minutes, then applied on 2\% agarose gel (15). The size of each genotype's ApaI, TaqI and BsmI were shown in Table 1. 


\subsection{Statistical analysis}

SPSS software version 16 (SPSS Inc., Chicago, IL, USA) was used for statistical analysis. The correlations were tested using Spearman's rho. ANOVA was used in comparisons performance. Both comparisons and correlations were considered statistically significant when $\mathrm{p}<0.05$.

Table 1. Forward and reverse primers.

\begin{tabular}{|l|l|l|}
\hline SNP & Sequences & Restriction products (bp) \\
\hline Apa1 & $\begin{array}{l}\text { Forward 5'-CAGAGCATGGACAGGGAGCAAG-3' } \\
\text { Reverse 5'-GCAACTCCTCATGGCTGAGGTCTCA-3' }\end{array}$ & $\begin{array}{l}\text { Allele AA: } 740 \\
\text { Allele Aa: } \\
\text { Allele aa: } 515+225\end{array}$ \\
\hline Taq1 & $\begin{array}{l}\text { Forward 5'-CAGAGCATGGACAGGGAGCAAG-3' } \\
\text { Reverse 5'-GCAACTCCTCATGGCTGAGGTCTCA-3' }\end{array}$ & $\begin{array}{l}\text { Allele TT: } 495+245 \\
\text { Allele Tt: } 495+290+245+205 \\
\text { Allele tt: } 290+245+205\end{array}$ \\
\hline BsmI & $\begin{array}{l}\text { Forward 5'-AGTGTGCAGGCGATTCGTAG-3' } \\
\text { Reverse 5'-ATAGGCAGAACCATCTCTCAG-3' }\end{array}$ & $\begin{array}{l}\text { Allele BB: } 360 \\
\text { Allele Bb: } 360+191+169 \\
\text { Allele bb: } 191+169\end{array}$ \\
\hline
\end{tabular}

\section{Results}

This study consists of 300 male students of applied medical sciences in Taif University, classified according to BMI into lean, overweight and obese groups. Table 2 represents a comparison of anthropometric and biochemical parameters between three groups by using ANOVA. It showed significant statistical difference in insulin [lean (54.22 \pm 14.55$)$, overweight (74.32 \pm 29.61$)$ and obese (109.44 \pm 39.91$)]$ with higher level in the obese group compared with the lean group $(\mathrm{p}=0.04)$. Moreover, HOMA-IR showed a significant statistical difference between all three groups with higher value in the obese group $(7.89 \pm 3.77)$ compared with the lean $(1.58 \pm 0.51)$ group $(\mathrm{p}=0.01)$. Our parameter of interest, $25-(\mathrm{OH})$ vitamin D showed significant statistical differences between three groups with lower level in the obese group $(12.7 \pm 6.1)$ compared with the lean $(29.5 \pm 8.7)$ group $(p=0.00)$. Table 3 represents the comparison of ApaI, TaqI and BsmI genotypes between lean, overweight and obese groups. The ApaI genotypes did not show significant difference between all three groups, but TaqI genotypes showed that th genotype had more frequency in the obese group compared with the lean group $(\mathrm{p}=0.021)$. Moreover, $\mathrm{t}$ allele is highly present in the obese group compared with the lean group $(\mathrm{p}=0.041)$. According to BsmI genotypes, the bb genotype showed higher frequency in the obese group compared with the lean group $(\mathrm{p}=0.042)$. In addition, the $\mathrm{b}$ allele showed high frequency in the obese group compared with the lean group $(\mathrm{p}=0.044)$. Table 4 represents the comparison between BMI, HOMA-IR and 25-(OH) vitamin D of different genotypes in the obese group, it showed that tt genotype of TaqI has higher BMI and HOMA-IR compared with TT and Tt genotypes ( $\mathrm{p}=0.048)$. In BsmI genotypes, the bb genotype has higher values in BMI and HOMA-IR compared with both BB and Bb genotypes $(p<0.05)$. Finally, ApaI genotypes did not show any significant statistical differences in any of the three parameters.

Table 2. Comparison between biochemical parameters of lean, overweight and obese groups using ANOVA $(\mathrm{Mean} \pm \mathrm{SD})$

\begin{tabular}{|l|l|l|l|l|}
\hline Variable & Lean; $\mathrm{n}=100$ & Overweight; $\mathrm{n}=100$ & Obese; $\mathrm{n}=100$ & $\mathrm{p}$-value \\
\hline Age $($ years $)$ & $27.25 \pm 4.30$ & $27.25 \pm 4$ & $27.25 \pm 4.37$ & 0.855 \\
\hline Height $(\mathrm{m})$ & $1.6 \pm 0.23$ & $1.7 \pm 0,07$ & $1.7 \pm 0.07$ & 0.0726 \\
\hline Weight $(\mathrm{kg})$ & $69.9 \pm 6.4$ & $83.8 \pm 6.6$ & $104 \pm 17.7$ & $0.001^{*}$ \\
\hline BMI $\left(\mathrm{kg} / \mathrm{m}^{2}\right)$ & $23.4 \pm 1.3$ & $27.7 \pm 1.2$ & $34.1 \pm 4.1$ & $0.002^{*}$ \\
\hline Cholesterol $(\mathrm{mg} / \mathrm{dL})$ & $169.43 \pm 12.25$ & $175.43 \pm 11.43$ & $183.65 \pm 10.76$ & 0.087 \\
\hline HDL $(\mathrm{mg} / \mathrm{dL})$ & $75.80 \pm 13.62$ & $71.65 \pm 12.34$ & $69.59 \pm 11.76$ & 0.230 \\
\hline LDL $(\mathrm{mg} / \mathrm{dL})$ & $99.5 \pm 8.121$ & $97,87 \pm 9.76$ & $98.78 \pm 7.87$ & 0.143 \\
\hline Insulin $(\mathrm{pmol} / \mathrm{L})$ & $54.22 \pm 14.55$ & $74.32 \pm 29.61$ & $109.44 \pm 39.91$ & $0.004^{*}$ \\
\hline HOMA-IR & $1.58 \pm 0.51$ & $3.23 \pm 2.43$ & $7.89 \pm 3.77$ & $0.001^{*}$ \\
\hline 25-H-Vit-D $(\mathrm{ng} / \mathrm{mL})$ & $29.5 \pm 8.7$ & $18.9 \pm 7.7$ & $12.7 \pm 6.1$ & $0.000^{*}$ \\
\hline
\end{tabular}

$* p<0.01$ 
http://www.ephysician.ir

Table 3. Comparison of ApaI, TaqI and BsmI genotypes and allelic frequencies between lean, overweight and obese groups

\begin{tabular}{|c|c|c|c|c|c|}
\hline \multicolumn{2}{|l|}{ Genotypes } & Lean; $\mathrm{n}(\%)$ & Overweight; $\mathrm{n}(\%)$ & Obese; n (\%) & p-value \\
\hline \multirow[t]{5}{*}{ Genotypes ApaI } & AA & $34(34)$ & $41(41)$ & $39(39)$ & 0.213 \\
\hline & $\mathrm{Aa}$ & $44(44)$ & $40(40)$ & $42(42)$ & 0.315 \\
\hline & aa & $22(22)$ & $19(19)$ & $19(19)$ & 0.382 \\
\hline & Allele A & $112(56)$ & $122(61)$ & $120(60)$ & 0.311 \\
\hline & Allele a & $88(44)$ & $78(39)$ & $80(40)$ & 0.321 \\
\hline \multirow{5}{*}{ Genotype TaqI } & TT & $42(42)$ & $46(46)$ & $28(28)$ & 0.091 \\
\hline & $\mathrm{Tt}$ & $40(40)$ & $41(41)$ & $34(34)$ & 0.182 \\
\hline & $\mathrm{tt}$ & $18(18)$ & $13(13)$ & $38(38)$ & $0.021 *$ \\
\hline & Allele T & $124(62)$ & $133(66.5)$ & $90(45)$ & 0.118 \\
\hline & Allele t & $76(38)$ & $67(33.5)$ & $110(55)$ & $0.041 *$ \\
\hline \multirow[t]{5}{*}{ Genotypes BsmI } & $\mathrm{BB}$ & $55(55)$ & $61(61)$ & $41(41)$ & 0.081 \\
\hline & $\mathrm{Bb}$ & $41(41)$ & $32(32)$ & $43(43)$ & 0.211 \\
\hline & $\mathrm{bb}$ & $4(4)$ & $7(7)$ & $16(16)$ & $0.042 *$ \\
\hline & Allele B & $151(75.5)$ & $154(77)$ & $125(62.5)$ & 0.145 \\
\hline & Allele b & $49(24.5)$ & $46(23)$ & $75(37.5)$ & $0.044 *$ \\
\hline
\end{tabular}

Table 4. Comparison between BMI, HOMA-IR and 25-(OH) vitamin D in each genotypes of ApaI, TaqI and BsmI in obese group

\begin{tabular}{|l|l|l|l|l|}
\hline ApaI genotypes & AA & Aa & aa & p-value \\
\hline BMI & $33.27 \pm 3.44$ & $32.56 \pm 3.01$ & $34.11 \pm 3.99$ & 0.421 \\
\hline HOMA-IR & $7.99 \pm 3.06$ & $7.21 \pm 3.22$ & $8.11 \pm 3.06$ & 0.213 \\
\hline 25-(OH) Vit D & $13.14 \pm 6.32$ & $12.66 \pm 5.02$ & $13.55 \pm 4.77$ & 0.138 \\
\hline TaqI genotype & TT & Tt & tt & p-value \\
\hline BMI & $32.11 \pm 1.14$ & $32.24 \pm 1.38$ & $36.18 \pm 2.11$ & $0.048^{*}$ \\
\hline HOMA-IR & $6.57 \pm 2.11$ & $7.89 \pm 2.57$ & $10.55 \pm 1.04$ & $0.029^{*}$ \\
\hline 25-(OH) Vit D & $14.55 \pm 4.02$ & $12.63 \pm 4.28$ & $10.59 \pm 4.21$ & 0.091 \\
\hline BsmI genotype & BB & Bb & bb & p-value \\
\hline BMI & $31.44 \pm 1.23$ & $32.95 \pm 1.36$ & $37.02 \pm 1.01$ & $0.023^{*}$ \\
\hline HOMA-IR & $6.11 \pm 1.89$ & $7.45 \pm 2.06$ & $10.03 \pm 1.40$ & $0.031^{*}$ \\
\hline 25-(OH) Vit D & $15.55 \pm 3.22$ & $15.77 \pm 2.71$ & $16.21 \pm 2.01$ & 0.422 \\
\hline$* P<0.05$ & \multicolumn{3}{|l}{} & \\
\hline
\end{tabular}

\section{Discussion}

Obesity has become an epidemic problem in different areas, and its rate is increasing around the world (16). Obesity results from a combination of different factors, such as hypovitaminosis. Vitamin D deficiency is still the silent problem around the world. Several studies in different ethics have shown a high rate of vitamin D deficiency including areas with prolonged sunshine. The study by Alharbi showed that $98 \%$ of Saudi males living in Jeddah, Saudi Arabia are suffering from vitamin D deficiency (17). Different types of studies in different countries showed association between obesity and low vitamin D level. Yingshui et al., in their 2015 study on 3,867 obese Chinese subjects found an association between vitamin D deficiency and obesity (18). Another study done in 2012 by Lee and his colleagues on Korean children showed an association between low vitamin D level and both visceral obesity and hypertriglyceridemia (19). Moreover, Afzal's study (20) showed inverse correlation between vitamin D supplementation and BMI. In accordance with several studies, our results showed a lower level of 25-(OH) vitamin $\mathrm{D}$ in obese Saudi men compared with lean subjects. In addition, our result showed an inverse correlation of $25-(\mathrm{OH})$ vitamin D levels with BMI values and insulin levels. The role of low vitamin D level and obesity development is unclear, but some studies explain the relation between these two parameters. Kull and his colleagues (21) suggest that obese people are less exposed to sun light than non-obese people, due to reduced physical activities. Another in vitro study done by Blum et al. (22) concluded that, low vitamin D levels in obese subjects is a result of sequestration of this vitamin by adipose tissue. The VDR have been demonstrated in adipose tissue so this tissue is a response to vitamin D signals (23). Previous studies conclude that, increase $25-(\mathrm{OH})$ vitamin D level is associated with weight loss. They found that an increase in vitamin D level by $2.7 \mathrm{ng} / \mathrm{mL}$ leads to a loss of about $5 \%-10 \%$ of 
baseline weight (24). The second factor with hypovitaminosis involved in obesity development, is genetic variations. Previously, several studies were done to determine the association of different gene polymorphisms and obesity, one of these genes involved in these studies is VDR. Vitamin D exhibits immune-modulatory and anti-proliferative effects through its receptor in disease state (25). The VDR gene is located at $12 \mathrm{q} 13$ chromosome and many polymorphisms are indicated at this region. The most important polymorphisms are ApaI, TaqI and BsmI which are covered by different studies in different areas and ethics (26). A previous study done by Wei-Zhen and his colleagues on a French population, found an association between BsmI genotypes and obesity (25). They found that a bb genotype is more susceptible to obesity than $\mathrm{BB}$ and $\mathrm{Bb}$ genotypes. Moreover, Al-Daghri and his colleagues (27) found an association between BsmI genotypes and obesity in a Saudi population. Fortunately, our study confirmed this association, and showed that the bb genotype is more susceptible to obesity than BB and Bb genotypes. Moreover, the bb genotype has higher BMI and HOMA-IR compared with other BsmI genotypes. On the other hand, a study done by Amar et al. (28) on Indian women did not confirm this association. According to TaqI genotypes, in 2011, a study done by Binh and his colleagues (29) on a Vietnamese population confirmed the association between TaqI genotypes and development of obesity. They found that tt genotypes have higher BMI compared with other genotypes, also their results showed a higher triglyceride value with low HDL value in tt genotype. Also, a recent study done by Saad and El-Askary (30) confirmed this association on an Egyptian population. Our results are similar to the results of these studies, we found that $t \mathrm{t}$ genotype is associated with obesity, and has higher BMI and HOMA-IR compared with TT and Tt genotypes. In contrast, a study done by Jakubowska et al. (31) on Polish people did not confirm this association. Finally, we did not confirm an association between ApaI genotypes and obesity, which has conflicting results to previous studies (32). Regarding the study limitations we should say that this study was conducted on Saudi male students, which represents a small size sample, so a large sample study is recommended to confirm the association of VDR polymorphism and obesity.

\section{Conclusions}

Our results showed a deficiency of vitamin D in young Saudi men, so vitamin D supplementation is recommended to prevent complication of this deficiency. We can conclude that there is an association between low vitamin D level and obesity in Saudi men. According to VDR genotypes, our results confirmed the association between BsmI and TaqI genotypes with obesity.

\section{Acknowledgments:}

This work was funded and carried out in Taif University with 100,000 SAR. We would like to thank everyone included in this work.

\section{Conflict of Interest:}

There is no conflict of interest to be declared.

Authors' contributions:

All authors contributed to this project and article equally. All authors read and approved the final manuscript.

\section{References:}

1) Non-communicable Diseases Country Profiles. Geneva, Switzerland: World Health Organisation: 2011: 209.

2) Nan C, Guo B, Warner C, Fowler T, Barrett T, Boomsma D, et al. Heritability of body mass index in preadolescence, young adulthood and late adulthood. Eur J Epidemiol. 2012; 27: 247-53. doi: 10.1007/s10654012-9678-6. PMID: 22426805.

3) Lavie CJ, McAuley PA, Church TS, Milani RV, Blair SN. Obesity and cardiovascular diseases: implications regarding fitness, fatness, and severity in the obesity paradox. J Am Coll Cardiol. 2014; 63: 1345-54. doi: 10.1016/j.jacc.2014.01.022. PMID: 24530666.

4) Habib SS. Body mass index and body fat percentage in assessment of obesity prevalence in Saudi adults. Biomed Environ Sci. 2013; 26: 94-9. PMID: 23336132.

5) Lazarevich I, Irigoyen-Camacho ME, Velazquez-Alva Mdel C. Obesity, eating behavior and mental health among university studentsin Mexico City. Nutr Hosp. 2013; 28: 1892-9. PMID: 24506365.

6) Parikh SJ, Edelman M, Uwaifo GI, Freedman RJ, Semega-Janneh M, Reynolds J, et al. The relationship between obesity and serum 1,25-dihydroxy vitamin D concentrations in healthy adults. J Clin Endocrinol Metab. 2004; 89: 1196-9. doi: 10.1210/jc.2003-031398. PMID: 15001609. 
7) Al-Hazmi AS. Relation of Vitamin D with Bone Mineral Density and Bone Turnover Markers in Healthy Saudi Men. International Journal of Advanced Research. 2016; 4: 205-11. doi: 10.21474/IJAR01/129.

8) Vimeswaran K, Berry D, Lu C, Pilz S, Hiraki L, Cooper J, et al. Causal relationship between obesity and vitamin D status: Bi-directional mendelian randomization analysis of multiple cohorts. PLoS Med. 2013; 10: 1549-676.

9) Simon Vanlint. Vitamin D and Obesity. Nutrition. 2013; 5: 949-56.

10) Wong K, Kong J, Zhang W, Szeto F, Ye H. Targeted expression of human vitamin D receptor in adipocytes decreases energy expenditure and induces obesity in mice. J Biol Chem. 2012; 286: 33804-10. doi: 10.1074/jbc.M111.257568. PMID: 21840998, PMCID: PMC3190828.

11) Ochs-Balcom H, Chennamaneni R, Millen A, Shields $P$, Marian C. Vitamin D receptor gene polymorphisms are associated with adiposity phenotypes. Am J Clin Nutr. 2011; 93(1): 5-10. doi: 10.3945/ajen.2010.29986. PMID: 21048058, PMCID: PMC3001595.

12) Vasilopoulos Y, Sarafidou T, Kotsa K, Papadimitriou M, Goutzelas Y. VDR TaqI is associated with obesity in the Greek population. Gene. 2013; 512(2): 237-9. doi: 10.1016/j.gene.2012.10.044. PMID: 23103831.

13) Ardawi MS, Sibiany AM, Bakhsh TM, Qari M, Maimani AA. High prevalence of vitamin D deficiency among healthy Saudi Arabian men: Relationship to bone mineral density, parathyroid hormone, bone turnover markers, and lifestyle factors. Osteoporos Int. 2010; 23: 675-86. doi: 10.1007/s00198-011-1606-1. PMID: 21625888.

14) Perrey C, Turner SJ, Pravica V, Howell W, Hutchinson IV. ARMS-PCR methodologies to determine IL10, TNF-alpha, TNF-beta and TGF-beta 1 gene polymorphisms. Trans Pl Immunol. 1999; 7: 127-8. doi: 10.1016/S0966-3274(99)80030-6.

15) Ye W, Reis A, Velho G. Identification of a novel Tru9 I polymorphism in the human vitamin D receptor gene. Journal of Human Genetics. 2000; 45: 56-7. doi: 10.1007/s100380050011. PMID: 10697965.

16) Mitchell NS, Catenacci VA, Wyatt HR, Hill JO. Obesity: Overview of an epidemic. Psychiatr Clin North Am. 2011; 34: 717-32. doi: 10.1016/j.psc.2011.08.005. PMID: 22098799, PMCID: PMC3228640.

17) Alharbi AS, Al-Omery A, Hedaib S. Prevalence of Vitamin D Deficiency among Healthy Saudi Men. Sch J App Med Sci. 2013; 1(6): 863-6.

18) Yingshui Y, Lijun Z, Lianping H, Ying D, Wei L, Zhonghua N, et al. A meta-analysis of the relationship between vitamin D deficiency and obesity. Int J Clin Exp Med. 2015; 8(9): 14977-84.

19) Lee S, Clark S, Gill R, Christakos S. 1,25-Dihydroxyvitamin D3 and pancreatic b-cell function: vitamin D receptors, gene expression, and insulin secretion. Endocrinology. 1994; 134: 1602-10. doi: 10.1210/endo.134.4.8137721. PMID: 8137721.

20) Afzal S, Brondum-Jacobsen P, Bojesen S, Nordestgaard B. Vitamin D concentration obesity, and risk of diabetes: a mendelian randomization study. Lancet Diabetes Endocrinol. 2014; 2: 298-306. doi: 10.1016/S2213-8587(13)70200-6.

21) Kull M, Kallikorm R, Lember M. Body mass index determines sunbathing habits: Implicationson vitamin D levels. Intern Med J. 2009; 39: 256-8. doi: 10.1111/j.1445-5994.2009.01900.x. PMID: 19402866.

22) Blum M, Dolnikowski G, Seyoum E, Harris S, Booth S, Peterson J, Saltzman E, Dawson-Hughes B. Vitamin D3 in fat tissue. Endocrine. 2008; 33: 90-4. doi: 10.1007/s12020-008-9051-4. PMID: 18338271, PMCID: PMC2839878.

23) Ding C, Gao D, Wilding J, Trayhurn P, Bing C. Vitamin D signaling in adipose tissue. Br J Nutr. 2012; 108: 1915-23. doi: 10.1017/S0007114512003285. PMID: 23046765.

24) Rock CL, Emond JA, Flatt SW, Heath DD, Karanja N, Pakiz B, et al. Weight loss is associated with increased serum 25-hydroxyvitamin D in overweight or obese women. Obesity. 2012; 20: 2296-301. doi: 10.1038/oby.2012.57. PMID: 22402737, PMCID: PMC3849029.

25) Ye WZ, Reis AF, Dubois-Laforgue D, Bellanné-Chantelot C, Timsit J, Velho G. Vitamin D receptor gene polymorphisms are associated with obesity in type 2 diabetic subjects with early age of onset. Eur J Endocrinol. 2001; 145: 181-6. doi: 10.1530/eje.0.1450181.

26) Bonakdaran S, Abbaszadegan M, Dadkhah E, Khajeh-Dalouie M. Vitamin D receptor gene polymorphisms in type 1 diabetes mellitus: a new pattern from Khorasan province, Islamic Republic of Iran. EMH J. 2012; 18: 614-9.

27) Al-Daghri N, Guerini F, Al-Attas O, Alokai S, Alkharfy K, Draz H, et al. Vitamin D Receptor Gene Polymorphisms Are Associated With Obesity and Inflammosome Activity. PLOS One. 2014; 9 (7): e102141. doi: 10.1371/journal.pone.0102141. PMID: 25020064, PMCID: PMC4096505. 
28) Amar N, Uppala S, Jupalle S, Krishan R, Medabalmi A. Vitamin D Receptor Gene Polymorphisms In Obese Indian Women With Polycystic Ovary Syndrome. Int J Curr Rese. 2015; 7: 19686-91.

29) Binh TQ1, Nakahori Y, Hien VT, Khan NC, Lam NT, Mai le B. Correlations between genetic variance and adiposity measures and gene $\times$ gene interactions for obesity in postmenopausal Vietnamese women. J Genet. 2011; 90: 1-9. doi: 10.1007/s12041-011-0028-3. PMID: 21677383.

30) Mohamed S, El-Askary A. Vitamin D Receptor Gene Polymorphism among Egyptian Obese Children. Asian J Clin Nutr. 2017; 9: 24-9. doi: 10.3923/ajen.2017.24.29.

31) Jakubowska-Pietkiewicz E, Klich I, Fendler W, Młynarski W, Chlebna-Sokół D. Effect of Vitamin D Receptor gene (VDR) polymorphism on body height in children-own experience. Postepy Hig Med Dosw (Online). 2013; 67: 873-8. doi: 10.5604/17322693.1063747. PMID: 24018452.

32) Clemente-Postigo M, Araceli M, Marta S, Ourdes G. Serum 25-Hydroxyvitamin D and Adipose Tissue Vitamin D Receptor Gene Expression: Relationship With Obesity and Type 2 Diabetes. JCEM. 2015; 10: 591-603. doi: 10.1210/jc.2014-3016. 